ECONOMICS

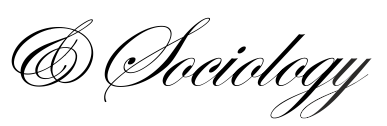

\author{
Kirsten Wüst, \\ University of Pforzheim, \\ Pforzheim, Germany, \\ E-mail:kirsten.wuest@,hs- \\ pforzheim.de
}

Mirna Leko Šimić, University of Osijek, Osijek, Croatia,

E-mail:lekom@efos.br

Received: February, 2017 1st Revision: March, 2017 Accepted: June, 2017

DOI: $10.14254 / 2071-$ 789X.2017/10-3/10

JEL Classification: J24
Wüst, K., Leko Šimić, M. (2017). Students' Career Preferences: Intercultural Study of Croatian and German Students. Economics and Sociology, 10(3), 136-152. doi:10.14254/2071-789X.2017/10-3/10

\section{STUDENTS' CAREER PREFERENCES: INTERCULTURAL STUDY OF CROATIAN AND GERMAN STUDENTS}

\begin{abstract}
Students' career preferences are an important issue to various stakeholders: to university administration, career counselors, higher education policy makers as well as to human resource managers in companies. Students, whose career preferences and goals are fulfilled, are better and more highly motivated employees. By a questionnaire survey carried out in 2016 in two institutions of higher education the present study compares career preferences and attitudes of 478 German and Croatian students. Factor analyses identify latent variables behind students' preferences. The identified significant differences between the Germans and Croatians are related to differences in socio-economic environment and cultural differences derived through the Hofstede model. German students value safe jobs, trust and a high income significantly more, whereas for Croatian students stimulating tasks, career opportunities, a recognized profession and social responsibility are more important. Our results indicate that Hofstede's findings for the uncertainty avoidance index and the individualism/collectivism index might be questioned for the subsample of a young student population who show different value criteria in their career preferences.
\end{abstract}

Keywords: career preferences; intercultural contexts; Germany; Croatia; Hofstede model.

\title{
Introduction
}

Numerous studies support that the socio-economic, cultural and political environment affect career preferences and choices of young people. There is extensive theoretical research on factors influencing students' career choices and preferences, but only a few studies have provided evidence on variations in career development preferences in different cultural and socio-economic contexts (Aycan \& Fikret-Pasa, 2003; Bullington \& Arbona, 2001).

The major task of this study was to identify differences in career development preferences between German and Croatian students and relate them to differences in the cultural and socio-economic environment of the two countries. The research is based upon theory developed by Bandura et al. (2001) that emphasizes the specific economic, social and cultural impact on career preferences. 
The significance of such a research can be viewed in both the theoretical and the practical context. In the theoretical context, it offers a testing of Hofstede's society model (Hofstede \& Hofstede, 2005) in the two different cultural environments of Germany and Croatia. In the practical context, research results can contribute to the existing knowledge on cultural influences on students' career preferences in the two countries. Monitoring students' preferences and understanding the cultural characteristics' impact on these preferences can help career counselors and university administrators, as well as labor and education policy makers and human resource management, i.e. recruiters of companies, in order to optimize their messages and services to students and job seekers.

\section{Literature review}

\subsection{Students' career choices and preferences}

The most of research on students' career choices in the last few years was concentrated on the identification of entrepreneurial or self-employment attitudes and intentions (Engle et al., 2010; Pruett et al., 2009; Solesvik, 2011 and others), specific fields of study or industry (Bundy \& Norris, 1991; Iacovou et al., 2011; Montgomery \& Ramus, 2011; Phillips et al., 1994; Wan et al., 2014), and nation-specific issues (Arulmani et al., 2003; Aycan \& FikretPasa, 2003; Ismail \& Lu, 2014; Tipurić et al., 2007). There is, to our best knowledge, only limited research on intercultural aspects of students' career development preferences and choices in sense of intercultural comparisons (Leong, 1991; Bobo et al., 1998; Browne, 1997; Lightbody et al., 1997; Ozbilgin et al., 2004). The major characteristics of this research are shown in Table 1.

Table 1. Overview of intercultural research on students ${ }^{6}$ career choices

\begin{tabular}{|c|c|c|c|}
\hline Authors & Year & Countries/cultures studied & Major findings \\
\hline Leong, F. T. V. & 1991 & $\begin{array}{l}\text { USA/ Asian American and } \\
\text { White American culture }\end{array}$ & $\begin{array}{l}\text { Asian Americans have greater preferences } \\
\text { for dependent decision-making styles, } \\
\text { lower level of career maturity and place } \\
\text { greater emphasis on extrinsic and security } \\
\text { occupational values. }\end{array}$ \\
\hline Browne, B. A. & 1997 & Australia and USA & $\begin{array}{l}\text { Emphasis on achievement through work } \\
\text { significantly higher in American culture. }\end{array}$ \\
\hline $\begin{array}{l}\text { Bobo, M., } \\
\text { Durodoye, B., \& } \\
\text { Hildreth, B. L. }\end{array}$ & 1998 & $\begin{array}{l}\text { USA/African-American, } \\
\text { Hispanic and Anglo culture }\end{array}$ & $\begin{array}{l}\text { Importance of socio-economic status and } \\
\text { political trends to different cultures. }\end{array}$ \\
\hline $\begin{array}{l}\text { Lightbody, P., } \\
\text { Nicholson, S., } \\
\text { Siann, G., \& } \\
\text { Walsh, D. }\end{array}$ & 1997 & $\begin{array}{l}\text { Great Britain/South Asian } \\
\text { and British culture }\end{array}$ & $\begin{array}{l}\text { Significant differences between cultures: } \\
\text { attainable social position and ability to } \\
\text { work with similar others more important } \\
\text { to South Asian culture, while personal } \\
\text { growth and autonomy more important to } \\
\text { British culture. }\end{array}$ \\
\hline $\begin{array}{l}\text { Ozbilgin, M., } \\
\text { Kusku, F., } \\
\text { Erdogmus, N. }\end{array}$ & 2004 & Great Britain, Israel, Turkey & $\begin{array}{l}\text { Belief of free career choice similar in all } \\
\text { three cultures. Entrepreneurial } \\
\text { orientation/self-employment significantly } \\
\text { higher in Israeli culture; career choice } \\
\text { mismatch significantly higher in Turkish } \\
\text { culture. }\end{array}$ \\
\hline
\end{tabular}


The above table indicates that significant differences with respect to different cultures regarding career choices exist, even though only two out of five analyzed cases were conducted in different countries that also take into account socio-economic macro environment.

There are five mostly used theories of students' career choice and preferences found in contemporary research. The three-item model of career choice (Beyon et al., 1998) is based on intrinsic (personal satisfaction, interest in job, etc.), extrinsic (job availability, prestige, financial benefits, etc.) and interpersonal elements (influence of parents or other reference groups).The second widely used model is the theory of planned behaviour applied in job search (van Ryn \& Vinokur, 1992) which analyzes three elements: attitude towards certain behaviour, i.e. a person's viewpoint on a specific career or job; subjective norm, i.e. the stand point of a person's reference groups (parents, friends, significant others) and perceived behavioral control, i.e. the degree of a person's perceived control over his/her actions. The third way of analysis of students' career choicesand preferencesis the theory of self-efficacy (Bandura, 2004) which measures believing in one's own capabilities of performing various roles and tasks. Several sources of perceived self-efficacy have been recognized: mastering experiences, modeling, social persuasion and judgement of ones' own psychological state. Holland's theory (Holland, 1997) of career choice is based on a fundamental underlying hypothesis which states that people will have the most job satisfaction in occupations that match their personality type and so tend to choose a career that is reflective of their personality. According to Holland's theory, there are 6 types of vocational personalities which predispose individuals to certain occupations: the realistic, investigative, artistic, social, enterprising and conventional type. The model is therefore also known as the RIASEC model.The most common way to measure career preferences in practice, advocated by careers advisers, is still Parsons' theory from as early as 1909 (Parsons, 1909), in which skills, values, interests and personality are analyzed and then matched with appropriate jobs. Many of the elements of these theories can be ascribed to cultural and socio-economic influences.

\subsection{Cultural Environment in Germany and Croatia}

Podrug, Filipović and Stančić (2014) have conducted a research of organizational culture differences in four countries, including Croatia and Germany using Hofstede's model (Hofstede \& Hofstede, 2005). In a survey conducted with an international sample of IBM employees Hofstede had asked the participants to rate the importance of fourteen work goals towards an "imaginary ideal job" (Dorfman \& Howell, 1988). Hofstede's original model was based on four indices that represent different aspects of culture:

- the power distance index, that measures the extent to which the less powerful members of a society expect and accept that power is distributed unequally. The authors have noted that the global trend is the lowering of power distance and that there is a correlation of this trend and the GDP growth rate of a country;

- the uncertainty avoidance index, which measures the extent to which members of the society feel threatened by uncertain and unknown situations;

- the individualism/collectivism index: in highly individualistic contexts relations between individuals are loose and everyone is expected to take care only of himself and the close family whereas in collectivistic cultures people belong to ,in-groups“ and the identity is based on the social network to which one belongs (Wursten \& Jacobs, 2013) - the masculinity/femininity index: a masculine society is a society in which gender roles are clearly distinct, while in feminine societies they tend to overlap.

Later on (Hofstede, 2011) the long-term/short-term orientation was added to the model: -a long-term orientation is an orientation toward future rewards, instead of wishes and wants related to the past and present as in a short-term orientation. 
Also, Hofstede developed a general overview of national cultures, taking into account not only employees but nationally repsresenative samples of population. Both Podrug, Filipović and Stančić research on national culutre and Hofstede research on both organizational and national culture have identified differences between German and Croatian culture.

Croatia is characterized by a higher power distance, higher uncertainty avoidance and a short term-orientation while Germany scores high on individualism and masculinity. Croatia scores high on the power distance index which means that people accept a hierarchical order in which everybody has a place and which needs no further justification. Hierarchy in an organization is seen as reflecting inherent inequalities, centralization is popular, subordinates expect to be told what to do and the ideal boss is a benevolent autocrat. Germany, on the other hand, is among the lower power distance countries. A direct and participative communication and meeting style are common, control is disliked. Leadership is challenged to show expertise and it is best accepted when based on expertism. (Hofstede, 2016)

The uncertainity avoidance index for Croatia shows a relatively high preference for avoiding uncertainty. Countries exhibiting high uncertainty avoidance maintain rigid codes of belief and behaviour and are intolerant of unorthodox behaviour and ideas. In these cultures there is an emotional need for rules (even if the rules never seem to work), time is money, people have an inner urge to be busy and work hard, precision and punctuality are the norm, innovation may be resisted and security is an important element in individual motivation. Uncertainty avoidance in Germany is still relatively high. There is a strong preference for deductive rather than inductive approaches, be it in thinking, presenting or planning: the systematic overview has to be given in order to proceed. In combination with Germany's low power distance index, where the certainty for own decisions is not covered by the larger responsibility of the boss, Germans prefer to compensate for their higher uncertainty by strongly relying on expertise (Schachner, 2016).

Considering individualism, Croatia is considered a collectivistic society, while Germany is a highly individualistic society. Collectivism manifests itself in a close long-term commitment to the member 'group', be that a family, extended family, or extended relationships. Employer/employee relationships are perceived in moral terms (like a family link), hiring and promotion decisions take account of the employee's in-group, management is the management of groups. Individualistic societies like Germany have a strong belief in the ideal of selfactualization. Loyalty is based on personal preferences for people as well as a sense of duty and responsibility. Communication is among the most direct in the world following the ideal to be "honest, even if it hurts" - and by this giving the counterpart a fair chance to learn from mistakes (Hofstede, 2016).

When analysing masculinity/femininity, Croatia is considered a relatively feminine society according to Hofstede \& Hofstede (2005). In feminine cultures the focus is on "working in order to live", managers strive for consensus, people value equality, solidarity and quality in their working lives. Conflicts are resolved by compromise and negotiation. Incentives such as free time and flexibility are favoured. The focus is on well-being, status is not shown. Values like cooperation at work, employment security and quality of life are important. In contrast, the German society, which is more masculine according to Hofstede \& Hofstede (2005), is driven by competition, achievement and success, with success being defined by the winner or the best in his field - a value system that starts in school and continues throughout organisational life (Hofstede, 2016).

Concerning long-term/short-term orientation Germany is positioned as a pragmatic country: Germans encourage thrift and efforts in modern education as a way to prepare for the future. In societies with a pragmatic orientation, people believe that truth depends very much on the situation, context and time. They show an ability to adapt traditions easily to changed conditions, a strong propensity to save and invest, thriftiness, and perseverance in achieving 
results. (Schachner) As a difference, countries with a short-term orientation, like Croatia, prefer to maintain time-honoured traditions and norms while viewing societal change with suspicion.

Additionally, changes in cultural influences format beliefs and values. Bai (1998), researching the Turkish cultural context, found that the emerging market economy has significantly contributed to changes in the value systems of students in a way that traditional values of sharing, equality, respect to authority and family are being replaced by self-interest, indivudualism, competition and achievement.

Since Croatia has been in a transition process for a prolonged and, due to war, very specific period we would assume that traditional values are still more present in Croatia than in Germany. However, research carried out by Tipurić, Podrug and Huška (2007) confirmed the ranking from Hofstede' s original work and additionally confirmed the trend of a decreasing power distance and significant movement towards individualism in Croatia, as well as in other considered countries (Slovenia, Bosnia and Herzegovina and Hungary).

The above discussed results were not derived from a student but from a general population. It is the aim of our paper to see whether the differences in cultural differences for the whole societies are reflected in student career preferences.

\subsection{Socio-economic environment in Germany and Croatia}

Table 2 shows a variety of socio-economic indicators in the EU, Germany and Croatia.

Table 2. Some socio-economic indicators in EU, Germany and Croatia, 2014

\begin{tabular}{lccc}
\hline & EU average & Germany & Croatia \\
\hline Social climate index total & -1.0 & 1.6 & -3.3 \\
\hline - personal circumstances & 2.5 & 4.0 & 1.30 \\
\hline - personal job situation & 1.2 & 3.2 & -1.5 \\
\hline - financial situation of the household & 0.8 & 2.3 & -1.3 \\
\hline - cost of living & -2.9 & 0.1 & -7.1 \\
\hline - economic situation & -2.6 & 3.6 & -7.6 \\
\hline - employment situation & -4.1 & 1.1 & -8.3 \\
\hline youth unemployment rate (2013) & 23.5 & 7.9 & 50.0 \\
\hline \% of employed (16+) with low job satisfaction & 19.4 & 24.3 & 25.4 \\
\hline \% of employees with temporary contract & 13.7 & 13.4 & 14.5 \\
\hline GDP per capita (EUR; 2015) & 26,300 & 34,100 & 10,400 \\
\hline
\end{tabular}

Source: Eurobarometer 418 (European Commission, 2015) - Social climate (-10: very bad to 10: very good)

It becomes clear from Table 2 that for Croatia all socio-economic indicators are significantly lower than for Germany or in the EU average. The most significant differences are in the area of costs of living, the economic situation in the country and the employment situation, which Croatian respondents have evaluated as the worst in the EU. Moreover, in the same Eurobarometer research, $42 \%$ of Croatian respondents had negative expectations about economic developments and $44 \%$ about employment chances during the next 12 months. These results show that the Croatian population is one of the most pessimistic in the EU. 


\section{Hypotheses}

It is the aim of our study to investigate whether cultural differences between Croatia and Germany as described by Hofstede \& Hofstede (2005) are also reflected in students' career preferences and choices. We therefore derive five hypotheses.

Croatia has a significantly higher uncertainty avoidance index according to the results of Podrug Filipović and Stančić and Hofstede. Additionally the employment situation is judged worse by the Croatian population than by the German population. Croatia also has a youth unemployment rate which is nearly three times the German one (see Table 2). From this we form our first hypothesis:

H1: Croatian students value secure jobs more than German students (eventually at the expense of career opportunities).

Germany has much higher individualism values according toand Hofstede's findings whereas Croatians are more collectivistic. We therefore derive two hypotheses for our study:

H2: Croatian students value ,, social responsibility“ more than German students. and:

H3: German students value individualistic values of their profession more (like enough leisure time, ,work-life-balance “, etc.) then Croatian students.

As the German society is, according to previously mentioned research, more masculine than the Croatian society we assume that masculine values are more important to German students than to Croatian ones, i.e.

H4: For German students success (high income, status) is more important than for Croatian students.

Because of the lower long-term-orientation of the Croatian society according to previously mentioned research, we further assume that

H5: Croatian students are more short-term orientated and therefore prefer static jobs, clear hierarchy.

\section{Methodological approach}

The study was conducted during summer semester 2016 at Pforzheim University of Applied Sciences, Germany by Kirsten Wüst and at the Faculty of Economics in Osijek by Mirna Leko Šimić, Croatia. Data was collected by means of a questionnaire. A convenience sample of altogether 478 university students participated in the survey, thereof 176 Germans $(36.8 \%)$ and 302 Croatians $(63.2 \%)$. The two sub-datasets of Croatian and German students were comparable with respect to age (M $\mathrm{M}_{\text {Germany: }}$ 21.9; $\mathrm{M}_{\text {Croatia: }}$ 21.81) and gender distribution (Germany: $33.1 \%$ male, $66.9 \%$ female; Croatia: $31.9 \%$ male, $68.1 \%$ female).

\subsection{Questionnaire}

For this study, we created a questionnaire based on questions in the youth questionnaire of the 30th version of the German Socioeconomic Panel (SOEP v30) (DIW Berlin/SOEP, 2013). The SOEP v30 is an annual representative panel survey of private German households that has been carried out since 1984. In addition to socio-demographic data we used question 55 of the SOEP v30 youth questionnaire that addressed the importance of certain aspects of professional life. It was measured on a four-point Likert scale $(1-$ not important at all, $2-$ less important, 3 - important, 4 - very important). The adopted question 92 the of the SOEP v30 youth questionnaire about attitudes towards life was measured on a seven-point Likert scale ( 1 - I do not agree at all, 7 - I totally agree). The questionnaire can be found in the Appendix. It was distributed in German to German students and in Croatian to Croatian students. We tested 
the comprehensibility and structure of the questionnaire in a pretest with students who were not included in the final sample.

\subsection{Statistical methods}

The statistics were computed with the statistical software package SPSS (IBM ${ }^{\circledR}$ SPSS ${ }^{\circledR}$ 22.0.0). Two-tailed statistics are reported throughout, a p-value less than $.05(\mathrm{p}<.05)$ is considered significant. The survey has an exploratory nature, so no adaptation of the significance level has been made for the multiple test situation.

Means and rankings are reported for the descriptive statistics of vocational expectations. The "vocational expectations" items are of an ordinal scale. The variables are ascribed values ("very important", "important", "less important", "not at all important"), which can, however, be regarded as being more or less equally spaced. The means and parametric tests, i.e. t-tests on differences, in the inductive analyses are therefore considered to be reasonable. The attitudes variables had values from " 1 - does not apply at all" to "7 - applies fully", with only the endpoints being depicted so that they could also be regarded as approximately metric. For means, we denote $\mathrm{M}$ with an index of the corresponding group. For the importance of certain aspects of professional life and for the attitude questions a principal component analysis (Hotelling, 1933) was carried out. We chose an orthogonal rotation (varimax rotation).

With the software Gpower, we calculated the needed sample size for a medium effect $\mathrm{d}=0.3$ (Cohen, 2013), unequal subgroups and a desired power of $80 \%$ which gave a necessary sample size of 115 in the smaller group and 173 in the larger group. In all t-tests we carried out for the aspects of professional life and the attitudes, our actual sample size was above the required one.

\section{Results}

Table 3 shows the means for the importance of aspects of professional life. For German students a „high income“ was significantly $(p<.001)$ more important than for Croatians. The difference between the two cultural subgroups was tested with an independent samples t-test. „Career opportunities" were significantly less important $(p=.001)$ to Germans than to Croatians. As we had expected the ,importance to society“ $(p<.001)$ and ,helping others“ $(p<.001)$ were significantly more important to Croatian students which supports our hypothesis H2. A „recognized profession“ $(p=.006)$ and „,working conditions“ $(p=.020)$ were also significantly more important to Croatians whereas ,contact to others“ was more important $(p=.030)$ to Germans. The ranking of the aspects of professional life was similar for German and Croatian students with slight shifts. For Croatians ,,importance to society“ as well as „helping others“ figured much higher in the ranking than for Germans, while a „high income“ only figured on rank 9 for Croatians compared to the first rank for German students.

Table 3. Means for the importance and ranking of certain aspects of professional life for German and Croatian students $\left(\mathrm{n}_{\text {German }}=172, \mathrm{n}_{\text {Croatian }}=272 ; *-\mathrm{p}<.05 ; * *-\mathrm{p}<.01 ; * * *-\mathrm{p}<.001\right)$

\begin{tabular}{lccccccc}
\hline & \multicolumn{2}{c}{ German } & \multicolumn{2}{c}{ Croatian } & \multicolumn{2}{c}{ Total } \\
\hline & Mean & Ranking & Mean & Ranking & p-value & Mean & Ranking \\
\hline \multicolumn{1}{c}{1} & 2 & 3 & 4 & 5 & 6 & 7 & 8 \\
\hline Secure position & 3.46 & 2 & 3.51 & 3 & .307 & 3.49 & 3 \\
\hline High income & 3.70 & 1 & 3.00 & 9 & $<.001^{* * *}$ & 3.27 & 5 \\
\hline Career opportunities & 3.31 & 5 & 3.50 & 4 & $.001^{* *}$ & 3.42 & 4 \\
\hline Recognized profession & 2.89 & 9 & 3.09 & 8 & $.006^{* *}$ & 3.01 & 8 \\
\hline Leisure time & 2.69 & 10 & 2.68 & 12 & .851 & 2.68 & 12 \\
\hline
\end{tabular}


RECENT ISSUES IN SOCIOLOGICAL RESEARCH

\begin{tabular}{lccccccc}
\hline \multicolumn{1}{c}{1} & 2 & 3 & 4 & 5 & 6 & 7 & 8 \\
\hline Stimulating tasks & 3.46 & 3 & 3.59 & 1 & $.049^{*}$ & 3.54 & 1 \\
\hline Independent work & 3.10 & 7 & 3.11 & 7 & .985 & 3.10 & 7 \\
\hline Contact to others & 3.07 & 8 & 2.89 & 11 & $.030^{*}$ & 2.96 & 9 \\
\hline Importance to society & 2.61 & 12 & 2.94 & 10 & $<.001^{* * *}$ & 2.81 & 11 \\
\hline Working conditions & 3.43 & 4 & 3.56 & 2 & $.020^{*}$ & 3.51 & 2 \\
\hline Time for family & 3.15 & 6 & 3.15 & 5 & .916 & 3.15 & 6 \\
\hline Helping others & 2.62 & 11 & 3.11 & 6 & $<.001^{* * *}$ & 2.92 & 10 \\
\hline
\end{tabular}

Source: own compilation.

Table 4 shows the means of the attitude scores towards certain aspects of life as well as differences between German and Croatian students tested with an independent samples t-test. Croatians highly significantly $(\mathrm{p}<.001)$ agree to „I am responsible for the course of my life“ and „You have to work hard for success“ as well as „When you are politically or socially engaged you can make changes". Contrary to our hypothesis (H5) of a Croatian short-term orientation, Croatians agreed highly significantly $(\mathrm{p}<.001)$ more to the statement „I pass today on things to be able to afford more tomorrow". For the „trust" items, i.e. to „In general one can trust people“ and „When you encounter new people it is important to be cautious before you trust them" (reversed item), Croatians agreed significantly less $(\mathrm{p}<.001)$.

Table 4. Means for attitudes towards certain aspects of life for German and Croatian students $\left(\mathrm{n}_{\text {German }}=164, \mathrm{n}_{\text {Croatian }}=258 ; *-\mathrm{p}<.05 ; * *-\mathrm{p}<.01 ; * * *-\mathrm{p}<.001\right)$

\begin{tabular}{lcccc}
\hline & Germ. & Croat. & Total & p-value \\
\hline I am responsible for the course of my life & 5.82 & 6.17 & 6.03 & $<.001^{* * *}$ \\
\hline Compared to others, I did not achieve what I deserved & 3.09 & 3.31 & 3.23 & .182 \\
\hline What you achieve in life is in first line a question of fortune & 3.34 & 3.57 & 3.48 & .140 \\
\hline I often experience that others decide about my life & 2.74 & 2.72 & 2.72 & .844 \\
\hline You have to work hard for success & 5.98 & 6.45 & 6.27 & $<.001^{* * *}$ \\
\hline When I experience difficult. in life I often question my skills & 4.12 & 4.03 & 4.07 & .542 \\
\hline I don't have a lot of control over things that happen in my life & 2.86 & 3.11 & 3.01 & .116 \\
\hline When you are politic. or soc. engaged you can make changes & 4.24 & 5.13 & 4.79 & $<.001^{* * *}$ \\
\hline I pass today on things to be able to afford more tomorrow & 4.97 & 5.50 & 5.29 & $<.001^{* * *}$ \\
\hline In general one can trust people & 4.14 & 3.36 & 3.66 & $<.001^{* * *}$ \\
\hline Today you cannot trust anybody any more. & 3.39 & 3.76 & 3.62 & $.039^{*}$ \\
\hline When you encounter new people it is important to be cautious & 4.94 & 5.48 & 5.27 & $<.001^{* * *}$ \\
\hline I want to have fun and do not think about tomorrow & 2.90 & 3.02 & 2.97 & .585 \\
\hline
\end{tabular}

Source: own compilation.

For the importance of certain aspects of professional life and for the attitude questions a principal component analysis with a varimax rotation was carried out. The scree-plot for the aspects of professional life suggested the extraction of four components. This corresponded to chosing all components with eigenvalues greater than 1 . The four extracted components explained 57\% of the variance (see Table 5). The first component (see Table 8 in the Appendix) had the marking variables "stimulating tasks", "independent work" and "contact to others" as well as a high loading of the variable "working conditions" and can be interpreted as the "task characteristics" (C1). The second component which comprises the marking variables "secure position", "high income", "career opportunities" and "recognized profession" stands for the "career" (C2) aspect of a profession. The third component had the marking variables "leisure 
time" and "time for the family" so that it can be interpreted as a "positive work-life-balance" (C3). The fourth component with the marking variables "Importance to society" and "helping others" stands for "social responsibility" (C4).

Table 5. Selected parameters of the factor analyses on aspects of professional life and attitudes $(*-\mathrm{p}<.05 ; * *-\mathrm{p}<.01 ; * * *-\mathrm{p}<.001)$

\begin{tabular}{lcc}
\hline & $\begin{array}{c}\text { Factor analysis } \\
\text { Aspects of prof. life }\end{array}$ & $\begin{array}{c}\text { Factor analysis } \\
\text { Attitudes }\end{array}$ \\
\hline KMO coefficient & .72 & .70 \\
\hline Bartlett-test on sphericity (p-value) & $<.001^{* * *}$ & $<.001^{* * *}$ \\
\hline Number of eigenvalues $>1$ & 4 & 4 \\
\hline Explained variance & $57.3 \%$ & $55.0 \%$ \\
\hline
\end{tabular}

Source: own compilation.

As Table 6 illustrates, German and Croatian students did not differ in their valuation of the "task characteristics" of the profession $(p=.443)$ nor did they significantly differ in the "career" aspect $(\mathrm{p}=.185)$. The difference was highly significant in the "social responsibility" component $(\mathrm{p}<.001)$ with Croatian students valuing "social responsibility" much more than German students.

Table 6. Means (standard deviations) for the difference of the four components of certain aspects of professional life derived in the factor analysis for German and Croatian students $(*-\mathrm{p}<.05 ; * *-\mathrm{p}<.01 ; * * *-\mathrm{p}<.001)$

\begin{tabular}{lccc}
\hline & German & Croatian & p-value \\
\hline task characteristics $(\mathrm{C} 1)$ & $0.46(1.01)$ & $-0.030 .99)$ & .443 \\
\hline Career $(\mathrm{C} 2)$ & $0.08(0.98)$ & $-0.05(1.00)$ & .185 \\
\hline leisure time $(\mathrm{C} 3)$ & $0.14(0.97)$ & $-0.09(1.00)$ & $.022^{*}$ \\
\hline time for the family $(\mathrm{C} 4)$ & $-0.59(0.76)$ & $0.38(0.94)$ & $<.001^{* * *}$ \\
\hline
\end{tabular}

Source: own compilation.

For the factor analysis of the attitude questions the item „In general one can trust people” was inverted to "In general one cannot trust people". The Bartlett-test on sphericity gave a highly significant result $(\mathrm{p}<.001)$, the KMO coefficient was .70 (see Table 5) so that the preconditions for appropriate correlations of the items are fulfilled (Bühner, 2006). Also for the attitudes, the scree-plot suggested the extraction of four components which corresponded to chosing all components with eigenvalues greater than 1 . The four factors explained $55 \%$ of the initial variance.

Table 9 in the appendix shows the loadings of the original attitudes questions on the four components. An analysis of the factor values gives insight into the differences between our student populations (see Table 7). German and Croatian students did not differ in their feeling of self-determination and control over their life (component $\mathrm{C} 1 \_\mathrm{a} ; \mathrm{p}=.726$ ) nor in the "hedonism" component (C4_a) $(\mathrm{p}=.990)$. They however differed significantly in "trust in others" (C2_a) $(\mathrm{p}<.001)$ with Croatian students trusting others much less. The difference was even higher in the "effort" component $\left(\mathrm{C} 3 \_a\right)(p<.001)$ with Croatian students valuing effort much more than German students. 
Table 7. Means (standard deviations) for the difference of the four components of attitudes derived in the factor analysis for German and Croatian students $(*-p<.05$; ** $-\mathrm{p}<.01$; $* * *-\mathrm{p}<.001)$

\begin{tabular}{lccc}
\hline & German & Croatian & p-value \\
\hline Self-determination (C1_a) & $-0.21(0.97)$ & $0.01(1.02)$ & .726 \\
\hline Trust in others (C2_a) & $-.26(1.03)$ & $0.17(0.94)$ & $<.001^{* * *}$ \\
\hline Effort $(\mathrm{C} 3$ a) & $-0.40(1.04)$ & $0.26(0.88)$ & $<.001^{* * *}$ \\
\hline Hedonism (C4_a) & $-0.00(1.01)$ & $0.00(0.99)$ & .990 \\
\hline
\end{tabular}

Source: own compilation.

\section{Discussion}

German students ranked ,a secure position“very high (2nd place in the ranking of items, $\mathrm{M}=3.46$ ). This is in line with big representative studies on German adolescents. In the 17th Shell youth study (Albert et al., 2015) a „secure job“ ranked first within eleven items referring to job characteristics (therein also ,a high income“, „enough leisure time“, etc.) for German young people aged 12 to 25 with $71 \%$ answering a ,secure job" would be ,very important" to them. The current high importance of ,secure jobs“ in Germany can be explained by the change in employment contracts in Germany. In 2016, only two thirds of the employees under 25 had permanent contracts while one-third worked in temporary contracts (Zeit online, 2016). 20 years ago the proportion of young employees with fixed contracts still figured to be $81 \%$. However, this does not seem to be the only reason for German young people to rate ,secure jobs" that highly. One can also compare the results of our study and the Shell youth study to former youth studies. In Saterdag and Kraft (1979) study, a "secure position" ranked first within a range of items comparable to our study with about $86 \%$ of the highschool students judging a secure position to be "very important". The importance of ,secure jobs" thus has a tradition for young people in Germany. The result is in line with the uncertainty avoidance index of Hofstede which also takes on a relatively high value for Germany.

However, against our expectations Croatian students did not value secure positions significantly more than German students. While for German students a secure position ranked second, for Croatian students „stimulating tasks“ and „working conditions“ were more important. Secure positions in Croatia are mainly those in the governmental or public sector. These jobs are secure, but the hierarchy is very rigid and it takes a long time to get to status, or earn more. In private businesses careers can be developed faster, however the private business is usually based on temporary contracts. The lower evaluation of secure jobs might thus be in line with the short-term orientation of Croatian culture and therefore with our fifth hypothesis. Matić (2006) studied the uncertainty avoidance index among Croatian and American undergraduate students and found out that Croatian undergraduate students, especially women, had rather low uncertainty avoidance indices. The population of students might thus have been specific in comparison to other populations with regard to the uncertainity avoidance index. Further research should elucidate on that question.

In line with our hypothesis ( $H 2)$ derived from the higher German individualism values according to the Hofstede findings, Croatian students valued "social responsibility" more than German students. "Helping others" figured on the sixth place for Croatians and on the penultimate for German students. While Germany has with $21 \%-30 \%$ a relatively low rate of volunteering (Aydinli et al., 2016), the number of adolescents who engage socially for one year (Freiwilliges Soziales Jahr (Voluntary Social Year), FSJ, and Freiwilliges Ökologisches Jahr (Voluntary Ecological Year 9, FÖJ) rises (Jakob, 2013). Also, the amount of young people 
stating that it is important for them to engage politically has risen from $22 \%$ in 2002 to $32 \%$ in 2015 (Statista.de, 2016). However, there seems to be a culture of only volunteering in order to improve one's CV. Volunteerism and helping others might thus not be an aim for themselves for German university students. Our data pointed in this direction. For Croatia, collectivistic values that stress "we" consciousness, loyalty to one's own group, importance of belonging to family and nation are all strongly present (Lažnjak, 2011). Therefore, helping others is also important. Additionally, Croatia's recent history of war with a huge amount of Croatian refugees having received help from others might play a role in students' felt importance of helping.

Contrary to our third hypothesis, German and Croatian students did not differ significantly on the "time aspects" of their profession. "Time for the family" was about equally important to both national groups. "Enough leisure time" was valued the least out of the given items for both student groups. For Germany, although with the Tagesbetreuungsausbaugesetz (Federal Daycare Facility Expansion Act) which is effective since 2013 parents have an institutional right for daycare for their children, the demand for institutional childcare still excels the offer. As childcare is still regarded the mother's responsibility women value flexibility at work even more than men (König \& Cesinger, 2015). In 2010, about $70 \%$ of the working women worked part-time whereas only $6 \%$ of the men did so (Keller \& Haustein, 2012). Women are thus to some extent more obliged to value "time for the family" in their job decisions. According to the latest Eurostat research (Eurostat 2016), Croatia is the country with the highest proportion of young people living together with their parents: over $70 \%$ of young people aged 18 to 34 still live with the parents and very often even three generations share the same household. Therefore we assume that the leisure time of Croatian students is obtained at the expense of other, older household members.

As expected by our fourth hypothesis German students ranked the masculine value of "a high income" very high and even regarded it as the most important feature of their future job. For German students a "high income" was even in the top position. This result is not in line with data from a representative sample of adolescents aged 12 to 25 of the Shell study in which "a high income" ranked on place eight out of twelve (Albert et al., 2015) nor with the representative sample of German 17-years old in which data from the German Socioeconomic Panel (SOEP v30) (DIW Berlin/SOEP, 2013) with the same items as in the current study was used and "a high income" figured on place 6 out of 12 (Wüst, 2015). In fact, the Hofstede results are also challenged on an international basis with regard to the masculinity/femininity dimension by Hoppe (1998) and Ashleigh Merrit's studies (2000) and the seminal GLOBE study (House et al., 2004). The authors argue that the Hofstede findings confound too many societal norms within only one dimension. For our student sample, the Hofstede masculinity for Germany could be found. Having put effort into their studies German students seem to expect an award which can be counted for in monetary units and rank a ,high income“ as their most important value (,should be“). The feminine values of the work being important to society, working conditions and helping others were significnatly higher for Croatian students, much more than a high income, as it was the case with German students. However, the Hofstede models' masculinity/femininity dimension can also be questioned in Croatia. Empirical research conducted on 513 employees and 715 students in the city of Zagreb, the capital of Croatia, in 1999, showed that the great majority of male respondents in Croatia are full of prejudices. For example, only $24.5 \%$ of working men and $27.5 \%$ of male students agreed that women can be good mothers and wives and be successful at work at the same time (Pološki, 2001). More recently, Jeknić (2013) research results placed Croatians among the more "masculine" societies. 


\section{Conclusion}

The aim of this research was to identify differences in career preferences between German and Croatian students and see whether they are related to cultural and socio-economic differences students live in. Some aspects of career preferences do differ significantly: the most important issues for German students are a high income, a safe job and contact to others while for Croatian students the most important aspects are stimulating tasks and working conditions. The importance of the job for society is much more important to Croatians than to Germans. While we could accept our hypothesis that Croatian students value „social responsibility“ more than German students and that for German students success in the form of a high income and status is more important than for Croatian students we had to reject the hyotheses that Croatian students value secure jobs more than Germans and that German students value individualistic values of their profession more. The Hofstede findings for the uncertainty avoidance index and the individualism/collectivism index might thus be questioned for the subsample of a young population (students) who show different value criteria in their career preferences. Employers in both countries will have to consider the changed preferences with regard to standard presumptions in order to be able to respond to the needs of young employees.

\section{References}

Albert, M., Hurrelmann, K., Quenzel, G., \& Schneekloth, U. (2015). Jugend 2015: Die 17. Shell Jugendstudie. //http://www.schule-wirtschaftsaarland.de/fileadmin/user_upload/ SchuleWirtschaft-Saar/Studien/Shell_Jugendstudie2015.pdf (reffered on: 22/11/2016). Arulmani, G., van Laar, D., \& Easton, S. (2003). The Influence of Career Beliefs and SocioEconomic Status on the Career Decision-Making of High School Students in India. International Journal for Educational and Vocational Guidance, 3(3), 193-204.

Ashleigh Merritt, A. (2000). Culture in the Cockpit: Do Hofstede's Dimensions Replicate? Journal of Cross-Cultural Psychology, 31(3), 283-301.

Aycan, Z., \& Fikret-Pasa, S. (2003). Career Choices, Job Selection Criteria, and Leadership Preferences in a Transitional Nation: The Case of Turkey. Journal of Career Development, 30(2), 129-144.

Bai, L. (1998). Monetary Reward Versus the National Ideological Agenda: Career choice among Chinese university students. Journal of Moral Education, 27(4), 525-540.

Bandura, A. (2004). Self Efficacy. In: Ramachaudran,V.S (ed.). Encyclopedia of Human Behaviour, NY: Academic Press, 71-81.

Bandura, A., Barbaranelli, C., Caprara, G. V., \& Pastorelli, C. (2001). Self-Efficacy Beliefs as Shapers of Children's Aspirations and Career Trajectories. Child Development, 72(1), 187-206.

Beyon, J., Toohey, K., \& Kishor, N. (1998). Do visible minority students of Chinese and South Asian ancestry want teaching as a career? Perceptions of some secondary school students in Vancouver, B.C. Canadian Ethnic Studies, 30(2), 50-73.

Bobo, M., Durodoye, B., \& Hildreth, B. L. (1998). Changing Patterns in Career Choices among African-American, Hispanic, and Anglo Children. Professional School Counseling, 1(4), $37-43$.

Browne, B. A. (1997). Gender and preferences for job attributes: a cross-cultural comparison. Sex Roles, 37(1/2), 61-71.

Bühner, M. (2006). Einführung in die Test- und Fragebogenkonstruktion. München: Pearson.

Bullington, R. L., \& Arbona, C. (2001). Career development tasks of Mexican American adolescents: An exploratory study. Journal of Career Development, 28(2), 139-153. 
Bundy, P., \& Norris, D. (1991). What accounting students consider important in the job selection process? Journal of Applied Business Research, 8(2), 1-6.

Cohen, J. (2013). Statistical Power Analysis for the Behavioral Sciences (2nd ed.). Hoboken: Taylor and Francis.

DIW Berlin/SOEP (2013). SOEP 2013 - Erhebungsinstrumente 2013 (Welle 30) des Soziooekonomischen Panels: Jugendfragebogen, Altstichproben. Berlin: SOEP Survey Papers. //www.econstor.eu/dspace/bitstream/10419/96129/1/782879748.pdf (reffered on: 12/11/2016).

Dorfman, P. W., \& Howell, J. P. (1988). Dimensions of National Culture and Effective Leadership Patterns: Hofstede Revisited. Advances in International Comparative Management, 3, 127-150.

Engle, R. L., Dimitriadi, N., Gavidia, J. V., Schlaegel, C., Delanoe, S., Alvarado, I., Wolff, B. (2010). Entrepreneurial intent. International Journal of Entrepreneurial Behavior \& Research, 16(1), 35-57.

European Commission (2015). Introduction of the Euro in the member states that have not yet adopted the common currency: Eurobarometer 418.

//ec.europa.eu/public_opinion/flash/fl_418_en.pdf (reffered on 2/10/2016)

Eurostat (2016). Share of young adults aged 18-34 living with their parents. //http://appsso.eurostat.ec.europa.eu/nui/show.do?dataset=ilc_lvps08\&lang=en (reffered on $13 / 9 / 2016)$

Hofstede, G. (2011). Dimensionalizing Cultures: The Hofstede Model in Context. Online Readings in Psychology and Culture, 2(1).

Hofstede, G.Geert Hofstede. https://geert-hofstede.com/germany.html (reffered on 25/8/2016).

Hofstede, G., \& Hofstede, G. J. (2005). Cultures and organizations: Software of the mind [intercultural cooperation and its importance for survival]. New York: McGraw-Hill.

Holland, J. L. (1997). Making vocational choices: A theory of vocational personalities and work environments (3. ed.). Lutz, Fla.: Psychological Assessment Resources.

Hoppe, M. H. (1998). Validating the Masculinity/Femininity Dimension on Elites from 19 Countries. En Masculinity and femininity: The Taboo Dimension of National Cultures, 29-43. Thousand Oaks: Sage Publications.

Hotelling, H. (1933). Analysis of a complex of statistical variables into principal components. Journal of Educational Psychology, 24, 417-441, and 498-520.

House, R. J., Hanges, P. J., Javidan, M., Dorfman, P. W., \& Gupta, V. (Eds.). (2004). Culture, leadership, and organizations: The GLOBE study of 62 societies. Thousand Oaks, Calif.: Sage Publications

Iacovou, C. L., Shirland, L., \& Thompson, R. L. (2011). Job Selection Preferences Of Business Students. Journal of Applied Business Research, 20(1).

Ismail, M., \& Lu, H. S. (2014). Cultural values and career goals of the millennial generation: An integrated conceptual framework. The Journal of International Management Studies, 9(1), 38-49.

Jakob, G. (2013). Freiwilligendienste zwischen Staat und Zivilgesellschaft. Friedrich-EbertStiftung.

Jeknić, R. (2013). Young women and culture:"masculinity"/"femininity" as cultural dimensions in Geert Hofstede's model of "national culture". Mlade žene i rodna ravnopravnost $\mathrm{u}$ postjugoslavenskim društvima: istraživanja, prakse i politike //https://bib.irb.hr/datoteka/656079.ywage_knjizica_sazetaka.pdf (reffered on:12/9/2016).

Keller, M. \& Haustein, T. (2012). Vereinbarkeit von Familie und Beruf - Ergebnisse des Mikrozensus 2010. Statistisches Bundesamt. 
König, S., \& Cesinger, B. (2015). Gendered work-family conflict in Germany: Do selfemployment and flexibility matter? Work, Employment \& Society, 29(4), 531-549.

Lažnjak, J. (2011). Dimensions of national innovation culture in Croatia - Content Validity of Hofstede's Dimensions. Drustvena istrazivanja, 20(4), 1015-1038.

Leong, F. T. L. (1991). Career Development Attributes and Occupational Values of Asian American and White American. The Career Development Quarterly, 39(3), 221-230.

Lightbody, P., Nicholson, S., Siann, G., \& Walsh, D. (1997). A respectable job: Factors which influence young Asians' choice of career. British Journal of Guidance \& Counselling, 25(1), 67-79.

Matić, J. (2006). The Degree of Uncertainty Avoidance Present in Croatian and American Undergraduate Students; a Comparative Analysis. Europe's Journal of Psychology. //http://ejop.psychopen.eu/article/view/291(reffered on 4/1/2016).

Montgomery, D. B., \& Ramus, C. A. (2011). Calibrating MBA job preferences for the 21st century. Academy of Management: Learning and Education, 10(1), 9-26.

Ozbilgin, M., Kusku, F., Erdogmus, N. (2004). Explaining influences on career choices in comparative perspective, Visiting Fellow Working Papers, Cornell University ILR School, http://digitalcommons.ilr.cornell.edu/intlvf (reffered on 10/9/2017).

Parsons, F. (1909). Choosing a vocation. Boston: Houghton Miffin.

Phillips, C. R., Phillips, A. S., \& Cappel, S. D. (1994). Research Note: How Management Students Select Prospective Employers. International Journal of Manpower, 15(1), 55-59.

Podrug, N., Filipović, D., \& Stančić, I. (2014). Analysis of cultural differences between Croatia, Brasil, Germany and Serbia. Economic Research, 27(1), 818-829.

Pološki, N. (2001). Basic Requirements for the Successful Implementation of the "Feminine Leadership" Style in Croatian Enterprises. Management, 6(1-2), 119-131.

Pruett, M., Shinnar, R., Toney, B., Llopis, F., \& Fox, J. (2009). Explaining entrepreneurial intentions of university students: A cross-cultural study. International Journal of Entrepreneurial Behavior \& Research, 15(6), 571-594.

Saterdag, H., \& Kraft, H. (1979). Ausbildungs-und Berufsperspektiven bei Jugendlichen gegen Ende der 9. Klasse. Mitteilungen aus der Arbeitsmarkt- und Berufsforschung, 105-124.

Schachner, M. How Germany's fondness of austerity is reflected in its culture. //http://consultants.itim.org/en/news/how-germanys-fondness-of-austerity-is-reflectedin-its-culture(reffered on 25/8/2016)

Solesvik, M. (2011). Attitudes toward future career choices. ICSB World conference Proceedings.

Statista.de. (2016). Wie wichtig findest Du es, sich politisch zu engagieren? (in den Jahren 2002 bis 2015) //https://de.statista.com/statistik/daten/studie/177136/umfrage/ wichtigkeitvon-politischem-engagement/(reffered on 19/12/2016).

Tipurić, D., Podrug, N., \& Hruška, D. (2007). Cultural differences: Results from empirical research conducted in Croatia, Slovenia, Bosnia and Herzegovina and Hungary. The Business Review, 7(1), 151-157.

van Ryn, M., \& Vinokur, A. D. (1992). How did it work? An examination of the mechanisms through which a community intervention influenced job-search behavior among an unemployed sample. American Journal of Community Psychology, 5, 557-597.

Wan, Y. K. P., Wong, I. A., \& Kong, W. H. (2014). Student career prospect and industry commitment: The roles of industry attitude, perceived social status, and salary expectations. Tourism Management, 40, 1-14.

Wursten, H. \& Jacobs, C. (2013). The impact of culture on education. The Hofstede Centre.

Wüst, K. (2015). Interesting tasks, independence or importance to society? - The vocational expectations of generation Y. Ekonomski vjesnik/Econviews, 28(2), 307-324. 
Zeit online (2016). Arbeitsmarkt: Anteil der unbefristet Beschäftigten nimmt ab. //http://www.zeit.de/wirtschaft/unternehmen/2016-08/arbeitsmarkt-unbefristetbeschaeftigte-abnahme (reffered on 28/11/2016). 


\section{Appendix}

\section{Questionnaire}

1. You are
a. Male
b. Female

2. Please indicate your age (open)

3. Please indicate your university term (open)

4. Please indicate your study program (open)

5. Do you still live with your parents?
a. Yes
b. No

6. How do you judge the financial situation of your parents?
a. Below average
b. Average
c. Above average

7. For the choice of a profession different aspects can play a role. Please indicate: How important are the following aspects for your vocational choice? $(1-$ not important at all, 2 - less important, 3 -important, 4 - very important)
a. Secure position
b. High Income
c. Career opportunities
d. Recognized profession
e. Leisure time
f. Stimulating tasks
g. Independent work
h. Contact to others
i. Importance to society
j. Working conditions
k. Time for family
1. Helping others

8. The following statements indicate different attitudes towards life and the future. Please indicate in how far you agree! ( 1 - I do not agree at all, 7 - I totally agree)
a. I am responsible for the course of my life
b. Compared to others, I did not achieve what I deserved
c. What you achieve in life is in first line a question of fortune
d. I often experience that others decide about my life
e. You have to work hard for success
f. When I experience difficult. in life I often question my skills
g. I don't have a lot of control over things that happen in my life
$\mathrm{h}$. When you are politically or socially engaged you can make changes
i. I pass today on things to be able to afford more tomorrow
j. In general one can trust people
k. Today you cannot trust anybody any more.
1. When you encounter new people it is important to be cautious
$\mathrm{m}$. I want to have fun and do not think about tomorrow 


\section{Additional tables}

Table 8. Rotated component matrix for the importance of certain aspects of professional life, coefficients with values lower 0.25 were oppressed

\begin{tabular}{lcccc}
\hline & $\mathrm{C} 1$ & $\mathrm{C} 2$ & $\mathrm{C} 3$ & $\mathrm{C} 4$ \\
\hline Secure position & & .578 & .296 & \\
\hline High Income & & .588 & & -.547 \\
\hline Career opportunities & .321 & .570 & -.364 & \\
\hline Recognized profession & & .664 & & .302 \\
\hline Leisure time & .656 & & .789 & \\
\hline Stimulating tasks & .773 & & & \\
\hline Independent work & .604 & & & \\
\hline Contact to others & .355 & .292 & & .636 \\
\hline Importance to society & .407 & .290 & .330 & .327 \\
\hline Working conditions & & & .790 & \\
\hline Time for family & & & .814 \\
\hline Helping others
\end{tabular}

Source: own compilation.

Table 9. Rotated component matrix for the attitude questions ("In general one can trust people" was inverted to "In general one cannot trust people"). Coefficients with values lower 0.25 were oppressed

\begin{tabular}{|c|c|c|c|c|}
\hline & $\mathrm{C} 1 \mathrm{a}$ & $\mathrm{C} 2 \mathrm{a}$ & $\mathrm{C} 3 \mathrm{a}$ & $\mathrm{C} 4 \_\mathrm{a}$ \\
\hline I am responsible for the course of my life & -.258 & & .713 & .289 \\
\hline Compared to others. I did not achieve what I deserved & .624 & & & \\
\hline $\begin{array}{l}\text { What you achieve in life is in first line a question of fate and } \\
\text { fortune }\end{array}$ & .501 & & & .330 \\
\hline I often experience that others decide about my life & .798 & & & \\
\hline You have to work hard for success & & & .683 & \\
\hline $\begin{array}{l}\text { When I experience difficulties in life I often question my } \\
\text { skills }\end{array}$ & 678 & & & \\
\hline $\begin{array}{l}\text { I do not have a lot of control over the things that happen in } \\
\text { my life }\end{array}$ & .724 & & & \\
\hline $\begin{array}{l}\text { When you are politically or socially engaged you can make } \\
\text { changes }\end{array}$ & & & .473 & \\
\hline I pass today on things to be able to afford more tomorrow & & & .551 & -.570 \\
\hline Today you cannot trust anybody any more. & & .796 & & \\
\hline When you encounter new people it is important to be cautious & & .665 & & \\
\hline I want to have fun and do not think about tomorrow & & & & .826 \\
\hline In general one cannot trust people & & .776 & & \\
\hline
\end{tabular}

Source: own compilation. 